TITLE:

\title{
Serpulid Polychaetes Associated with Living and Dead Corals at Okinawa Island, Southwest Japan
}

AUTHOR(S):

Nishi, Eijiroh

\section{CITATION:}

Nishi, Eijiroh. Serpulid Polychaetes Associated with Living and Dead Corals at Okinawa Island, Southwest Japan. PUBLICATIONS OF THE SETO MARINE BIOLOGICAL LABORATORY 1996, 37(3-6): 305-318

ISSUE DATE:

1996-12-25

URL:

http://hdl.handle.net/2433/176262

RIGHT: 


\title{
Serpulid Polychaetes Associated with Living and Dead Corals at Okinawa Island, Southwest Japan
}

\author{
EIJIROH NISHI \\ Natural History Museum and Institute, Chiba, Aoba-cho 955-2, \\ Chuo-ku, Chiba 260, Japan
}

\begin{abstract}
I investigated coral-reef polychaetes in order to clarify their ecological habits, especially their association with living and dead coral in Okinawa, and provide here brief taxonomic accounts. Altogether, 25 species of 15 genera were found, and 12 serpulid species are found associated with living coral; 2 species, Spirobranchus corniculatus (Grube, 1862) and Floriprotis sabiuraensis Uchida (1978) seems to be obligate inhabitants of living corals. On dead coral skeletons, 24 serpulid species occurred. Four forms of association between serpulids and corals can be distinguished: I) buried in living coral skeletons, II) worm tubes partly covered by living coral skeletons, III) worm tubes running on the surface of living corals, and IV) whole tubes attached to dead coral skeleton.
\end{abstract}

Key words: Serpulid polychaete, coral associates, coral reef, Okinawa

\section{Introduction}

The biology of coral-reef serpulid polychaetes is not well known, though more than 30 species are presently known to exist in the Okinawan islands. The coral-boring polychaete Spirobranchus giganteus Pallas is the only species for which various information regarding its taxonomy and ecology is available. The habitats of coral-reef serpulid polychaetes have been usually recorded simply as intertidal, rock, dead coral, living coral, or fouling organisms (see Imajima, 1987, regarding Okinawan serpulids).

Many serpulid polychaetes associated with living and dead corals were collected duirng the studies of annelid fauna around Okinawa Islands. By closer observation on these specimens, the serpulids were noticed to inhabit differently live and/or dead corals, not always clearly known facultatively or obligately, although the habit of living of the coral-reef serpulid polychaetes had been commonly noted just as "buried in living coral" or "attached to dead coral skeleton".

In this paper, the modes of association of the serpulid polychaete species with host coral species are compared and summarized, and the taxonomical and ecological accounts are given for these serpulid species.

\section{Study Sites, Materials and Methods}

The survey of serpulid polychaetes associated with dead corals were done on 20 dead colonies of Pocillopora damicornis, Acropora spp. and Porites spp. that were collected by myself by hand or using chiesel and hammer at Sesoko Island, just off Motobu in northern part of Okinawa Osland, June, 1992. Additional samplings were done during 1991 to 1995 on living and dead coral skeletons at Sesoko Island, Maeda Cape and Zampa Cape, southern central part of Okinawa Island. All the serpulids obtained were identified to the species level where possible.

Specimens were deposited in Natural History Museum and Institute, Chiba (CBM-ZW), or uncatalogued because of drying on SEM stab. 


\section{Results and Discussion}

In total 23 species of Serpulidae occurred on over 20 coral species (Table 1). On living corals, 12 serpulid species occurred (Table 1); except for Spirobranchus corniculatus (Grube, 1864) and Floriprotis sabiuraensis Uchida (1978), all the rest species also occurred on dead coral. On dead coral skeletons, 22 serpulid species, including 5 unidentifiable species, occurred (Table 1). Morphological description and taxonomical and ecological remarks are noted below.

The habits of association of serpulids on living corals can be separated into following 4 types. 1) Tubes wholly embedded in living coral skeletons have openings not buried in living coral tissues; Scott (1987) defined a "living infaunal associate" as one that lives in the coral skeleton and whose aperture opens through the living coral tissue. II) Some or most part of the tube is embedded in the coral skeleton, with the remaining top part of the tubes lying on the living coral or erected upwards. III) Tubes lying attached over the surface of the living coral skeleton. IV) Whole tubes attached to dead coral skeletons. Detailed habit of association between serpulid polychaetes and corals are noted in remarks if possible.

\section{Filogranella sp.}

Material examined: CBM-ZW-188 (colony of worms), Sesoko Island, Okinawa, July 20, 1990, 1-2m deep, on dead coral skeletons.

\section{Floriprotis sabiuraensis Uchida, 1978}

Floriprotis sabiuraensis Uchida, 1978, pp. 18-19: Nishi, 1992a, pp. 16-17.

Serpula spec., 2?: ten Hove, 1994, pp. 111-112.

Material examined: CBM-ZW-163 (tube is preserved in ethanol, trunk on SEM stab), Maeda Cape, Okinawa Island, 1-2 m deep, August 20, 1991.

Description: The body size is 15 to $20 \mathrm{~mm}$ in total length. The tube was buried in the coral skeletons and white and smooth on the inner surface. The operculum is absent. The thoracic membrane covers all the thoracic segments. The collar setae are of two types; capillary and blade setae. Abdominal setae are geniculate.

Remarks: Three specimens from living corals appeared in Zampa Cape, Maeda Cape, and Sesoko Island. Only one worm could be collected and tentatively described (Nishi, 1992a). $\mathrm{Up}$ to now, this species is reported to attach only on the living coral inclusive of my unpublished data (in Amakusa, west Kyushu, this species occurred commonly buried in living coral: CBM-ZW-179 (1 worm), Ushibuka, Amakusa, west Kyushu, about 10m deep, on live coral, November 19, 1993).

\section{Hydroides elegans (Haswell, 1883)}

Hydroides elegans (Haswell, 1883): ten Hove, 1974, p. 46; Imajima, 1976b, pp. 237-238; Nishi, 1993a, p. 12.

Material examined: CBM-ZW-159 (2 worms), Sesoko Island, Okinawa, 1-2m deep, on living coral, July $27,1991$.

Remarks: Two specimens on living corals and over 20 worm underside of dead corals occurred. This species occurred abundantly on the wall and shells in the aquarium (Nishi, 1993b). 
Table 1. List of serpulid polychaetes found associated with living and dead corals at Okinawa, 1991-1995.

\begin{tabular}{|c|c|}
\hline Serpulid species & Coral species associated with serpulid \\
\hline \multicolumn{2}{|c|}{ Buried in coral skeleton } \\
\hline Hydroides elegans & Montastrea sp. \\
\hline Hydroides exaltata & Pocillopora damicomis \\
\hline Serpula cf. watsoni & Porites cylindrica \\
\hline \multirow[t]{36}{*}{ Spirobranchus corniculatus } & Pavona decussata \\
\hline & Pocillopora damicornis \\
\hline & Pocillopora vermucosa \\
\hline & Porites rus \\
\hline & Porites cylindrica \\
\hline & Porites lutea \\
\hline & Porites nigrescens \\
\hline & Porites contigua \\
\hline & Acropora sp. \\
\hline & Goniastrea sp. \\
\hline & Goniastrea retiformis \\
\hline & Stylophora pistillata \\
\hline & Psammocora digitata \\
\hline & Psammocora sp. \\
\hline & Montastrea annulata \\
\hline & Caurastrea sp. \\
\hline & Echynopola sp. \\
\hline & Montipora informis \\
\hline & Montipora hispida \\
\hline & Montipora sp. \\
\hline & Cyphastrea microphthalma \\
\hline & Pectinia sp. \\
\hline & Hydnophora sp. \\
\hline & Acanthastrea echinata \\
\hline & Acropora digitifera \\
\hline & Acropora nobilis \\
\hline & Acropora aspera \\
\hline & Millepora platyphylla \\
\hline & Favites abdida \\
\hline & Favites chinensis \\
\hline & Favites russelli \\
\hline & Favites sp. \\
\hline & Platygyra pini \\
\hline & Platygyra ryukyuensis \\
\hline & Favia speciosa \\
\hline & Favia pallida \\
\hline Spirobranchus tetlaceros & Porites cylindrica \\
\hline \multirow[t]{2}{*}{ Vermiliopsis infundiburum glandigera } & Pavona decussata \\
\hline & Goniopora lobata \\
\hline \multirow{2}{*}{ Floriprotis sabiuraensis } & Porites lutea \\
\hline & Cyphastrea sp. \\
\hline
\end{tabular}




\begin{tabular}{|c|c|}
\hline Serpulid species & Coral species associated with serpulid \\
\hline \multicolumn{2}{|c|}{ Partly buried in coral skeleton } \\
\hline Pomatostegus stellatus & $\begin{array}{l}\text { Cyphastrea sp. } \\
\text { Pavona decussata }\end{array}$ \\
\hline \multicolumn{2}{|c|}{ Attached to the surface of living coral tissues } \\
\hline Salmacina dysteri & $\begin{array}{l}\text { Pocillopra damicornis } \\
\text { Pavona divaricata }\end{array}$ \\
\hline Paraprotis dendrova & Pocillopora verrucosa \\
\hline Rhodopsis pusilla & Porites cylindrica \\
\hline Josephella marenzelleri & Porites cylindrica \\
\hline \multicolumn{2}{|c|}{ Attached to dead coral skeleton } \\
\hline Hydroides elegans & Pocillopora damicornis \\
\hline Hydroides exaltata & Pocillopora damicomis \\
\hline Hydroides tambalagamensis & Acropora sp. \\
\hline Serpula cf. watsoni & Pocillopora damicornis \\
\hline Serpula cf. kaempferi & Porites cylindrica \\
\hline Serpula cf. vittata & Porites sp. \\
\hline Pomatoleios kraussii & Porites sp. \\
\hline Pomatostegus stellatus & Porites cylindrica \\
\hline \multirow[t]{3}{*}{ Protula tubularia } & Pocillopora damicomis \\
\hline & Porites cylindrica \\
\hline & Acropora sp. \\
\hline Paraprotis dendrova & Acropora sp. \\
\hline Salmacina dysteri & Pocillopora damicomis \\
\hline \multirow[t]{2}{*}{ Rhodopsis pusilla } & Acropora sp. \\
\hline & Pocillopora damicomis \\
\hline Josephella marenzelleri & Porites sp. \\
\hline Vermiliopsis infundiburum glandigera & Porites sp. \\
\hline Vermiliopsis sp. & Pocillopora damicornis \\
\hline Filogranella sp. & Pocillopora damicornis \\
\hline Metavermilia sp. & Acropora sp. \\
\hline Spirobranchus tetlaceros & Pocillopora damicomis \\
\hline Spirobranchus polytrema & Acropora sp. \\
\hline Pseudovermilia sp. & Acropora sp. \\
\hline Protula sp. & Acropora sp. \\
\hline
\end{tabular}

\section{Hydroides exaltata (Marenzeller, 1884)}

Eupomatus exaltata Marenzeller, 1884: Willey, 1905, pp. 312-313; Pixell, 1913, pp. 11-18; Imajima \& Hartman, 1964, p. 368.

Hydroides exaltata (Marenzeller, 1884): Dew, 1959, pp. 27-28; Pillai, 1960, pp. 10-12; Straughan, 1967, p. 220; Imajima, 1976b, pp. 127-128; Imajima, 1987, p. 77.

Material examined: Two worms on living coral, two on dead coral skeletons (one wom on SEM stab, preserved materials lost), July 27, 1991. 


\section{Hydroides tambalagamensis Pillai, 1961}

Hydroides tambalagamensis Pillai, 1961, pp. 36-38: Straughan, 1967, p. 33; Imajima, 1976a, pp. 123125; Imajima, 1987, p. 76.

Material examined: CBM-ZW-148 (1 worm), Sesoko Island, Okinawa, 1-2 m deep, on dead coral skeleton, April 10, 1992.

\section{Josephella marenzelleri Caullery \& Mesnil, 1896}

(Fig. 4f)

Josephella marenzelleri Caullery \& Mesnil, 1896, pp. 484-486-36: Dew, 1959, pp. 52-53; Uchida, 1978, pp. 34-36; Imajima, 1979, p. 181; Bailey-Brock, 1991, pp. 199-201; Nishi, 1992c, pp. 109110.

Material examined: CBM-ZW-141 (1 worm), Sesoko Island, Okinawa, 1-2 m deep, on living coral, July 27, 1991.

Remarks: Some worms occur on dead and living corals, usually with Rhodopsis pusilla Bush, 1904. This species is about the same in body size as $R$. pusilla Bush, 1904, and characterized by chitinous cup-like opercular plate (Fig. 4f). This species is colonial, and perform asexual reproduction (Nishi, 1992c) as in R. pusilla Bush, 1904 (Nishi \& Yamasu, 1992c). Rhodopsis pusilla Bush, 1904 and J. marenzelleri Caulley \& Mesnil 1896 can not be distinguished by external tube morphology except for the presence of brood chamber of the former species.

\section{Metavermilia sp.}

(Fig. 2e, f)

Material examined: CBM-ZW-138 (1 worm), Sesoko Island, Okinawa, 1-2 m deep, on dead coral skeleton, July 27, 1991; CBM-ZW-167 (1 worm), Sesoko Island, Okinawa, 1-2 m deep, on dead coral skeleton, July $27,1991$.

\section{Paraprotis dendrova Uchida, 1978}

(Fig. 4e)

Paraprotis dendrova Uchida, 1978, pp. 16-17: Nishi, 1992b, p. 18; Nishi \& Yamasu, 1992b, p. 85.

Material examined: CBM-ZW-157 (4 worms), Sesoko Island, Okinawa, on aquarium wall of Sesoko Marine Science Center, $1 \mathrm{~m}$ deep, March 10, 1992; CBM-ZW-156 (10 worms), Sesoko Island, Okinawa, underside of dead coral skeleton, 2-3 m deep, July 27, 1991; uncatalogued dried specimen on SEM stab ( 6 juveniles), Sesoko Island, Okinawa, 1-2 m deep, on dead coral skeleton, October 21, 1991; uncatalogued dried specimen on SEM stab (5 specimens), Sesoko Island, Okinawa, 1-2 $\mathrm{m}$ deep, on dead coral skeleton, October 21, 1991.

Remarks: This species is a solitary small species without operculum, with unique reproductive apparatus. Among the branchial crown, a pair of brooding appendages with many eggs and larvae occur (Fig. 4e; Nishi, 1992a; Nishi \& Yamasu, 1992b). Tube is usually erected and whirled as in spirorbid polychaete. This species usually occurred on aquarium wall (Nishi, 1992a), and rarely did underside of dead coral skeleton.

\section{Pomatoleios kraussii (Baird, 1865)}

Pomatoleios kraussii (Baird, 1865): Nishi, 1993b, p. 10; Nishi, 1993c, pp. 32-36.

Materials examined: None, identified in field. 


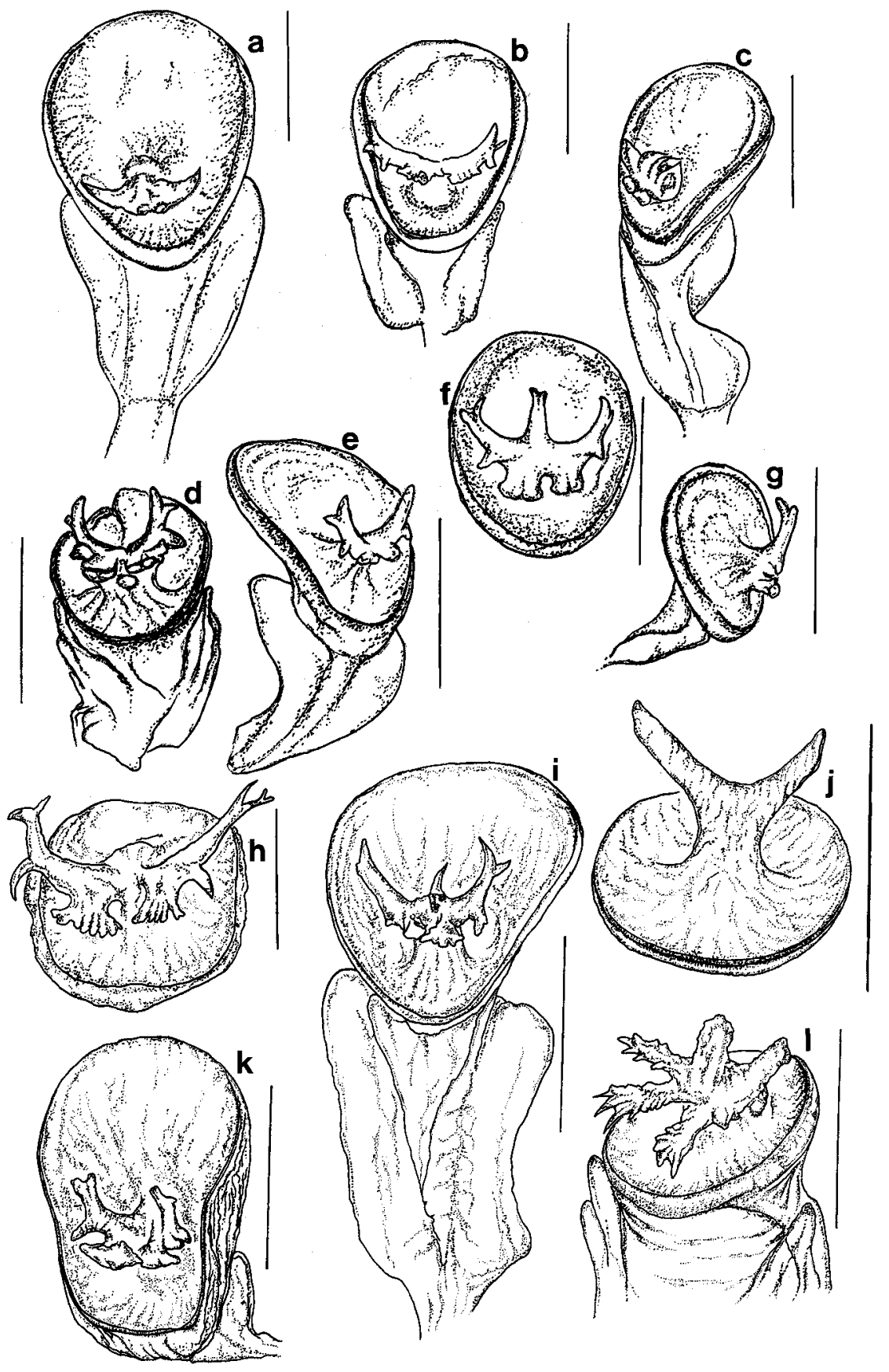

Fig. 1. Operculum of Spirobranchus corniculatus (a to k) and Spirobranchus tetlaceros (l). $\mathrm{f}, \mathrm{h}$, and $\mathrm{j}$ show only opercular plate, others opercular plate and peduncle. a: CBM-ZW-168; b: CBM-ZW-168; c: CBM-ZW-168; d: CBM-ZW165; e: CBM-ZW-172; f: CBM-ZW-54; g: CBM-ZW-170; h: CBM-ZW-169; i; CBM-ZW-171; j: CBM-ZW-23; k: CBM-ZW-175; 1: CBM-ZW-140. Scale bars: $1 \mathrm{~mm}$. 

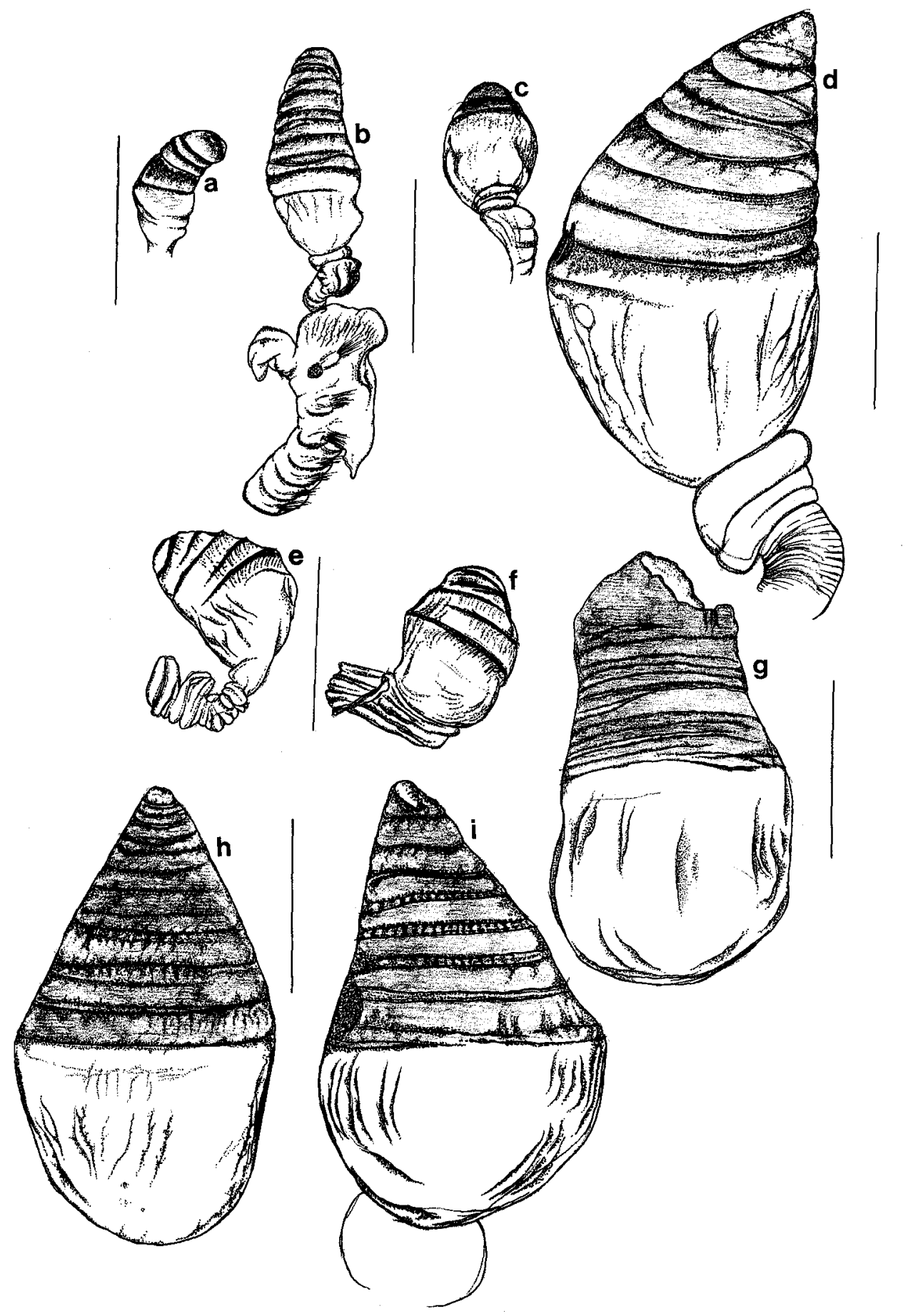

Fig. 2. Operculum of Vermiliopsis infundiburum/glandigera (a-d, h, and i), Vermiliopsis sp. $(\mathrm{g})$ and Metavermilia sp. (e and $\mathrm{f}$ ). b shows operculum and thoracic part. a: CBM-ZW-144; b: CBM-ZW-144; c: CBM-ZW-164; d: CBM-ZW-143; e and f: CBM- ZW138; g: CBM-ZW-145; h: CBM-ZW-143; i: CBM-ZW-143. Scale bars: $1 \mathrm{~mm}$. 


\section{Pomatostegus stellatus (Abildgaard, 1789)}

Pomatostegus stellatus (Abildgaard, 1789): Pixell, 1913, p. 79; Okuda, 1937, pp. 309-311; Dew, 1959, pp. 41-42; Pillai, 1960, pp. 23-25; Straughan, 1967, p. 238; Imajima, 1979, pp. 101-102; Imajima, 1987, p. 80; Nishi, 1995a, pp. 29-31.

Material examined: CBM-ZW-139 (1 worm), Sesoko Island, Okinawa, 1-2 m deep, on living coral; CBM-ZW-47 (1 worm), Sesoko Island, Okinwa, 2-3m deep, on living coral, May 12, 1992; uncatalogued dried specimen (3 worms), Sesoko Island, Okinawa, 1-2 m deep, on dead coral skeleton, October 20, 1991.

\section{Protula tubularia (Montagu, 1803)}

Protula tubularia (Montagu, 1803): Uchida, 1992, p. 144.

Material examined: CBM-ZW-153 (1 worm), Sesoko Island, Okinawa, 1-2 m deep, on dead coral skeleton, May 12, 1992; CBM-ZW-154 (1 worm), Sesoko Island, Okinawa, 1-2 m deep, on living coral, July 27, 1991.

\section{Protula sp.}

Material examined: CBM-ZW-189 (1 worm), Sesoko Island, Okinawa, 1-2 m deep, on dead coral skeletons, May 12, 1992.

\section{Pseudovermilia? sp.}

Material examined: CBM-ZW-164 (1 worm), Sesoko Island, Okinawa, 1-2 m deep, on dead coral skeleton, July 27, 1991.

\section{Rhodopsis pusilla Bush, 1904}

Rhodopsis pusilla Bush, 1904, pp. 289-290: Ben-Eliahu \& ten Hove, 1989, p. 383; Bailey-Brock, 1991, pp. 201-204; Nishi \& Yamasu, 1992c, pp. 34-39; ten Hove \& San Martin, 1995, p. 19.

Material examined: CBM-ZW-159 (2 worms), Sesoko Island, Okinawa, 1-2 m deep, on living coral, July 27, 1991.

Remarks: Colonies of worms occur on dead corals and the surface of living corals (Table 1). This minute species is characterized by a chitinous opercular plate (showing dimorphism) bearing numerous spines (Fig. 4a-c; see also Ben-Eliahu \& ten Hove, 1989). Pouch-like brood chambers on the tube associated with rings making peristome were found on some tubes (Fig. 4d). This species occurred abundantly on bare concrete wall and on shells in the aquarium (Nishi, 1993a,b; Nishi \& Yamasu, 1992c).

\section{Salmacina dysteri (Huxley, 1855)}

Salmacina dysteri (Huxley, 1855): Nishi, 1993b, pp. 12-14; ten Hove, 1994, p. 110.

Material examined: CBM-ZW-155 (2 specimens), Sesoko Island, Okinawa, 1-2m deep, on living coral, July 27, 1991; CBM-ZW-162 (3 specimens), Sesoko Island, Okinawa, 2-3 m deep, on living coral, January 23, 1992.

Remarks: The tubes are entangled and form colonies on various substrates (Nishi \& Nishihira, 1993, 1994; Nishi \& Yamasu, 1992a). On living Porites cylindrica and Pavona decussata, their tubes occurred, and the base of the colony was found out on dead part of the corals. 


\section{Serpula cf. Kaempferi (Kinberg, 1867)}

(Fig. 3a-f)

Serpula cf. kaempferi (Kinberg, 1867): Imajima, 1978, pp. 50-52.

Material examined: CBM-ZW-160 (2 worms), Sesoko Island, Okinawa, 2-3 m deep, on dead coral skeleton, January 31, 1992; CBM-ZW-161 (3 worms), Sesoko Island, Okinawa, 2-3 m deep, on dead coral skeletons, January 31, 1992; CBM-ZW-166 (1 worm), Sesoko Island, Okinawa, 1-2 m deep, on dead coral skeletons, July 27, 1991.

\section{Serpula cf. vittata Augener, 1914}

(Fig. $3 g-j$ )

Serpula vittata Augener, 1914, pp. 137-139: Imajima, 1979, pp. 160-162; Imajima, 1987, p. 79; ten Hove, 1994, p. 111.

Material examined: CBM-ZW-151 (1 worm), Sesoko Island, Okinawa, 1-2 m deep, on dead coral skeleton, July 27, 1991; CBM-ZW-152 (1 worm), Sesoko Island, Okinawa, 1-2 m deep, on dead coral skeleton, July $27,1991$.
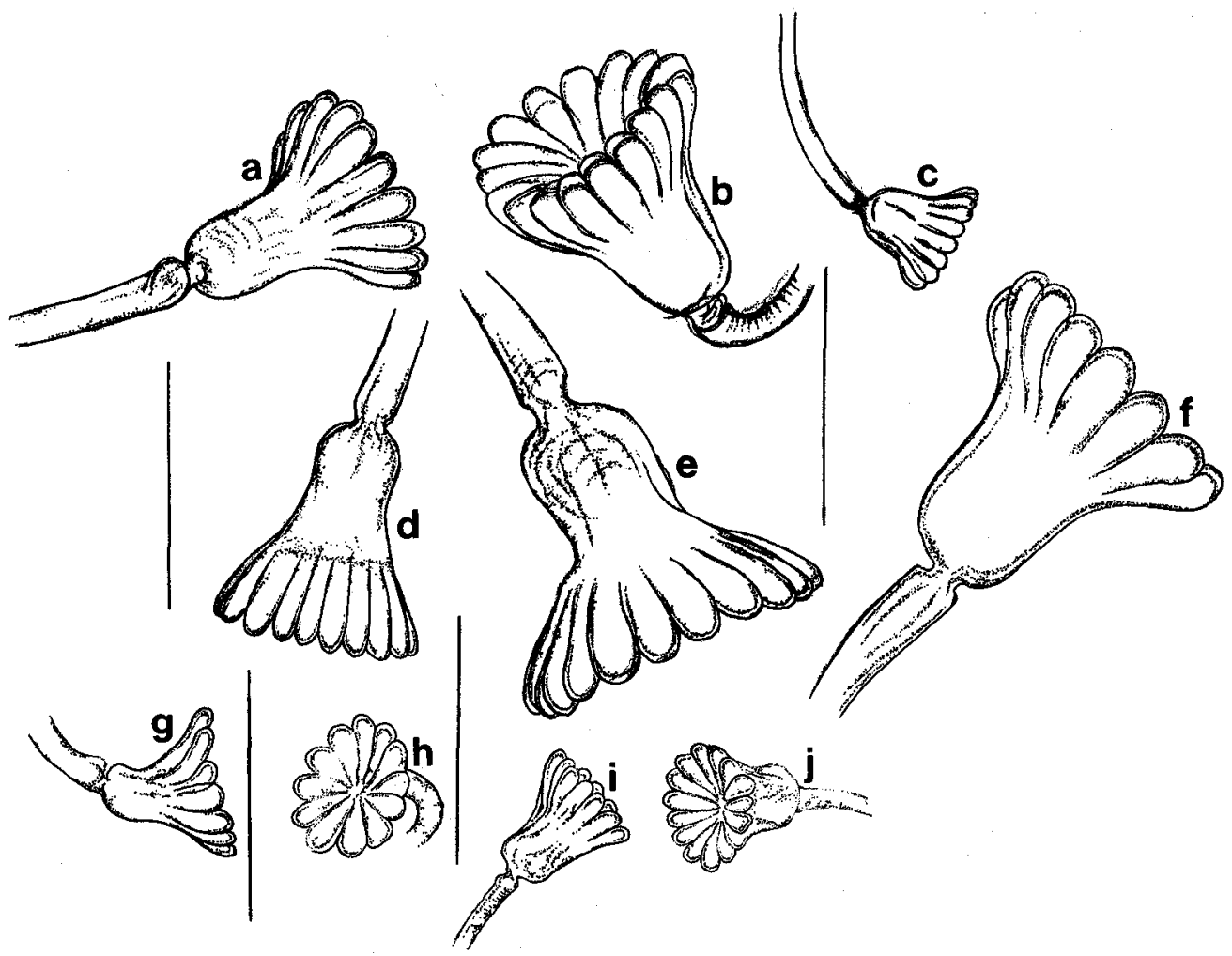

Fig. 3. Operculum of genus Serpula. a to f: Serpula cf. kaempferi; $g$ to $j$ : Serpula vittata. a: CBM-ZW-161; b: CBM-ZW-161; c: CBM-ZW-161; d: CBM-ZW-166; e: CBM-ZW-160; f: CBM-ZW-160; g: CBM-ZW-152; i and j: CBM-ZW-151. Scale bars: $1 \mathrm{~mm}$. 


\title{
Serpula cf. watsoni Willey, 1905
}

Serpula watsoni Willey, 1905, p. 317: Imajima, 1977, pp. 91-92; Imajima, 1987, p. 78; Nishi, 1992b, pp. $79-80$.

Material examined: Uncatalogued dried specimen on SEM stab (1 worm), Maeda Cape, Okinawa, 23m deep, on living coral, March 2, 1992.

\section{Spirobranchus corniculatus (Grube, 1862)}

\author{
(Fig. 1a-k)
}

Serpula corniculatus Grube, 1862, p. 66.

Spirobranchus giganteus Pallas, 1766: Fauvel, 1836, p.87-89.

Spirobranchus giganteus corniculatus ten Hove, 1970, p. 24-32: Imajima , 1987, p. 80; Nishi \& Asakura, 1996, pp. 56-60.

Material examined: CBM-ZW-53 (1 specimen), Zampa Cape, Okinawa, subtidal, 1-3 $\mathrm{m}$ deep, on living coral Montastrea sp., May 20, 1992; CBM-ZW-54 (1 specimen), Zampa Cape, Okinawa, subtidal, 1-3 m deep, on living coral, Montastrea sp., January 27, 1993; CBM-ZW-165 (8 specimens), Zampa Cape, Okinawa, 2-5 m deep, on living coral, May 4, 1995.

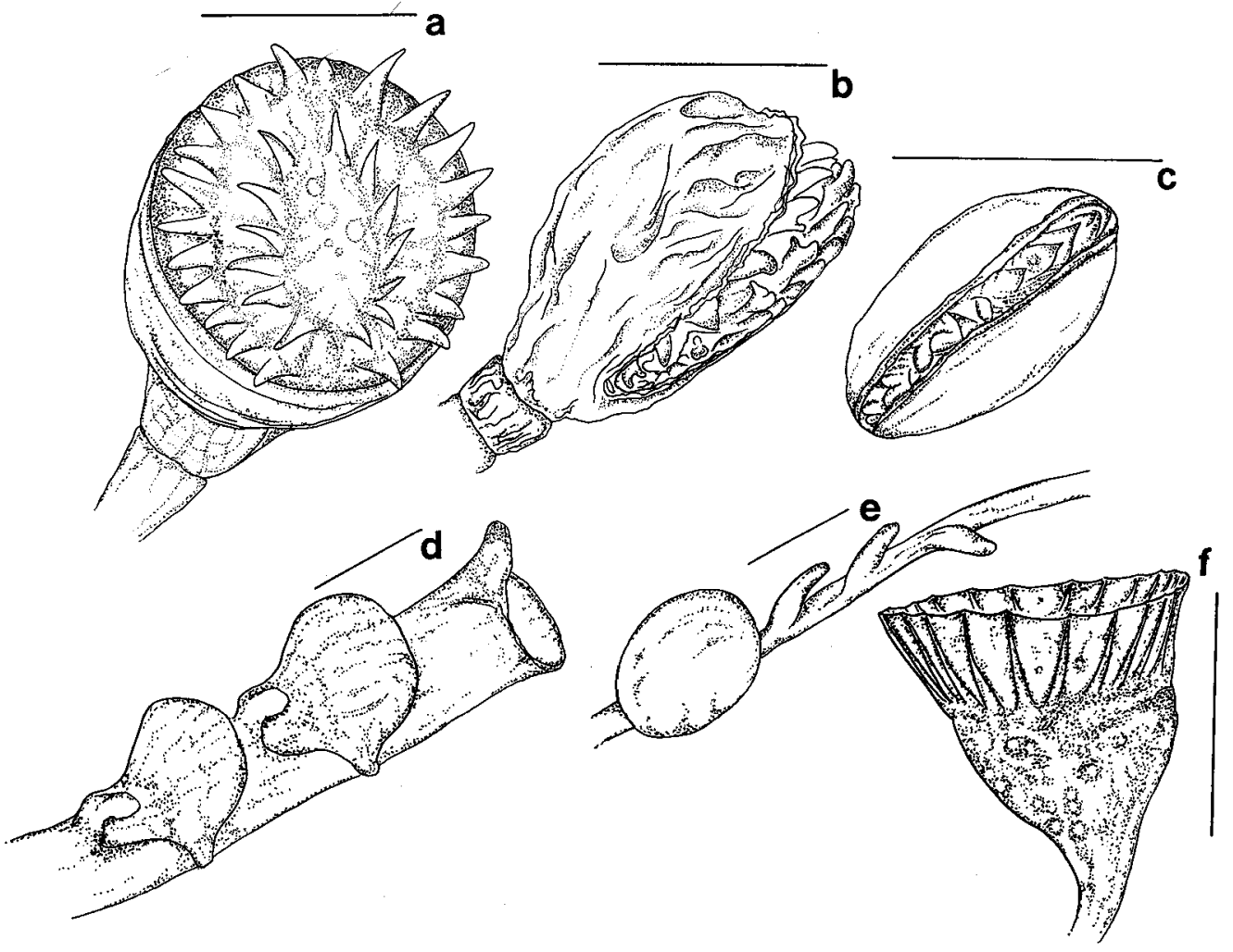

Fig. 4. Operculum and reproductive apparatus of Rhodopsis, Josephella, and Paraprotis. a to c: operculum of Rhodopsis pusilla; d: brooding chamber of $R$. pusilla on tube; e: brooding appendage with one egg of Paraprotis dendrova; f: operculum of Josephella marenzelleri. Scale bars: 0.05 $\mathrm{mm}$. 
Description: Worms measure 4-90 $\mathrm{mm}$ from the tip of the operculum to the posterior end of the abdomen. The morphology of the opercular plate is varied among the worms; it is usually wide and has a short central spine that divides into two, four or five branches, each of which commonly divides into fine spines (Fig. la-k). Small worms below $5 \mathrm{~mm}$ in body length were found on the outside of living corals and their operculum bears simple spines (Fig. 1j). The opercular plate is nearly flat (Fig. 1g,j) or deeply concave (Fig. 1a-c,i,k), and the plate is usually from semi-circular to egg-shaped. The plate edge is commonly tinged with pale pink, and the rest part of the plate is white or cream-coloured. The opercular peduncle is somewhat flattened with lateral wings extending half to two-third the length of the peduncle. The lateral wings have entire edge and a rounded distal tip (Fig. Ib,e,i). There are seven thoracic segments, six of which are uncinigerous; collar setae is "Spirobranchus" type and penetrates the base of the collar.

Over 200 worms were observed on 37 living coral species (Table 1), and 30 woms were collected from 12 species of corals.

Remarks: This species is associated with over 30 species of corals in Okinawa (this study) and 32 species in Taiwan (Dai \& Yang, 1995). Because Spirobranchus giganteus (Pallas, 1766) inhabits many coral species (ten Hove, 1989; Scott, 1987), ten Hove (1989) noted that there appears to be no preferential selection of coral species. Contrary, Marsden et al. (1990) have shown that the planktonic larvae of S. giganteus (Pallas, 1766) prefer certain coral species for settlement. Hunte et al. (1990) noted a non-random distribution of S. giganteus (Pallas, 176) on corals. Nishi \& Kikuchi (1996) also noted a non-random distribution of S. corniculatus (Grube, 1862) on corals at Okinawa. The host coral preference of Spirobranchus worm is possibly different with the sea areas concerned, but more detailed studies, like works on Spirobranchus at coral reefs of Taiwan by Dai \& Yang (1995), are needed for confirmation.

Spirobranchus corniculatus (Grube, 1862) is obligately associated with living corals at Okinawa, and almost all of the worms are fully embedded in coral skeletons. Very rarely, a few adult worms have been found attached to bare coral skeletons (only 5 instances among over 1000 worms), but the host coral was probably alive when the polychaete juvenile was alive. Neverthless, this species frequently occurred on bare natural rocks and dead coral skeletons in Izu Peninsula, central Japan (CBM-ZW-185, 1 worm; CBM-ZW-186, 1 worm), and rarely on live coral (CBM-ZW-183, 1 worm; CBM-ZW-184, 3 worms).

\section{Spirobranchus cf. polytrema (Philippi, 1844)}

Spriobranchus polytrema (Philippi, 1844): Straughan, 1967, p. 230; Pillai, 1971, pp. 94-96; Imajima, 1977, pp. 102-106; Imajima, 1987, p. 79.

Material examined: Uncatalogued one worm on SEM stab.

\section{Spirobranchus tetlaceros (Schmarda, 1861)}

(Fig. 11)

Spirobranchus tetlaceros (Schmarda, 1861): ten Hove, 1970, pp. 3-14; Imajima, 1979, pp. 177-178; Imajima, 1987, p. 79.

Material examined: CBM-ZW-140 (1 worm), Sesoko Island, Okinawa, 1-2m deep, on living coral (Porites sp.), July 27, 1991.

Description: The tube is round in cross section, and a median ridge and some indistinct longuitudial ridges ornament the tube. The tube is basically white but tinged with pale pink. Radioles and opercular stalk are banded with blue. The branchial membrane extends one-thirds the length of the radiole. The opercular plate has six branches from one common 
base, and each branch bears lateral fine spines (Fig. 11). The peduncle has lateral wings along its entire length, and the tips are not divided.

Remarks: Only two worms were found out; one is buried in living coral, Porites sp., and the other under dead coral skeleton. From S. corniculatus (Grube, 1862), this species can be easily distinguished by the opercular and tube morphology.

\section{Vermiliopsis infundiburum / glandigera}

(Fig. 2a-d, h-j)

Vermiliopsis infundiburum / glandigera: Imajima, 1976a, pp. 139-141 (for synonymy); Imajima, 1987, p. 80; ten Hove, 1994, p. 113; Nishi, 1995a, pp. 28-29.

Material examined: CBM-ZW-142 (1 worm), Sesoko Island, Okinawa, 1-2 m deep, on live coral, March 20, 1992; CBM-ZW-143 (5 worms), Sesoko Island, on concrete aquarium wall of Sesoko Marine Science Center, $1 \mathrm{~m}$ deep, January 16, 1992; CBM-ZW-144 (1 worm), Sesoko Island, Okinawa, 1-2 m deep, on dead coral skeleton, July 27, 1991; CBM-ZW-164 (1 worm), Sesoko Island, Okinawa, 1-2 m deep, on dead coral skeleton, March 20, 1992.

Description: The operculum is composed of a fleshy ampulla and a conical, brown chitinous cup, divided into 2 to 5 layers by partitions (Fig. $2 \mathrm{~d}, \mathrm{~h}, \mathrm{i}$ ). The peduncle is round in cross section, and its surface is wrinkled.

Remarks: Three worms occurred on living corals and 10 worms underside the dead corals. The tubes were buried in coral skeletons except for the aperture, or only a small portion of the tube was covered by living corals. This species is a form with variable opercular features, and is now placed under the complexed taxa Vermiliopsis infundiburum / glandigera (ten Hove, 1975; ten Hove \& Wolf, 1984; Nishi, 1995a).

\section{Vermiliopsis sp.}

(Fig. 2g)

Material examined: CBM-ZW-145 (1 worm), Sesoko Island, Okinawa, 1-2 m deep, on dead coral skeleton, July 27, 1991.

\section{Acknowledgements}

I am most grateful to Dr. Mark J. Grygier for correcting English and providing invaluable comments, and to Dr. E. Harada and anonymous reviewers for useful suggestions on the manuscript. I also wish to thank Dr. T. Yamasu and the members of the staff of Department of Biology, Division of General Education, University of the Ryukyus, for their help in field works and laboratory treatment of the samples.

\section{References}

Augener, H. 1914. Polychaeta. Sedentaria. In: Michelson \& Hartmeyer, Die Fauna SudwestAustraliens, 5: 1-170.

Bailey-Brock, J.H. 1991. Tubeworms (Serpulide, Polychaeta) collected from sewage outfalls, coral reefs and deep waters off the Hawaiian Islands, including a new Hydroides species. Bull. Mar. Sci., 48: 198-207.

Ben-Eliahu, M.N. \& ten Hove, H.A. 1989. Redescription of Rhodopsis pusilla Bush, a little known but widely distributed species of Serpulidae (Polychaeta). Zool. Scr., 18: 381-395.

Bush, K.J. 1904. Tubicolous annelids of the tribes Sabellides and Serpulides from the Pacific Ocean. Harriman Alaska Exp., 12: 169-355.

Caullery, M. \& Mesnil, F. 1896. Note sur deux Serpuliens nouveaux (Oriopsis metchnikowi n. g., n. 
sp. et Josephella marnzelleri n. g., n. sp.). Zool. Anz., 10: 482-486.

Dai, Cheng-Feng \& Yang, Hsiao-Pei. 1995. Distribution of Spirobranchus giganteus corniculatus

(Hove) on the coral reefs of Southern Taiwan. Zool. Stud., 34: 117-125.

Dew, B. 1959. Serpulidae (Polychaeta) from Australia. Rec. Aust. Mus., 25: 19-56.

Fauvel, P. 1936. Annelides Polychetes du Japon. Mem. Coll. Sci., Kyoto Univ., ser. B., 12: 41-92.

Grube, A.E. 1862. Mittheilungen uber die Serpulen, mit besonderer Berucksichtigung ihrer Deckel.

Jahresb. Abh. Schles. Ges. Breslau, 39: 53-69.

ten Hove, H.A. 1970. Serpulidae (Polychaeta) from the Carribean: I - the genus Spirobranchus.

Stu. Faun. Curacao, Carribean Isl., 32: 1-57.

ten Hove, H.A. 1974. Notes on Hydroides elegans (Haswell, 1883) and Mercierella enigmatica Fauvel, 1923, alien serpulid polychaetes introduced into the Netherlands. Bull. Zool. Mus., Univ. Amsterdam, 4: 45-51.

ten Hove, H.A. 1975. Serpulinae (Polychaeta) from the Carribean. III. The genus Pseudovermilia, including species from other regions. Stud. Faun. Curacao, Carr. Is1., 47: 46-101.

ten Hove, H.A. 1989. Serpulinae (Polychaeta) from the Carribean. IV - Pseudovemilia madraciola sp. n., a symbiont of corals. Studies in honour of Dr. Pieter Wagenaar Hummelinck. Foundation for scientific research in Surinam and the Netherlands Antilles, Amsterdam, 23: 135-144.

ten Hove, H.A. 1994. Serpulidae (Annelida, Polychaeta) from the Seychelles and Amirante Islands. In: J. van der Land (ed.), Oceanic Reefs of the Seychelles. Cruise Reports Neth. Indian Ocean Program, II, Nat. Hist. Mus., Leiden, pp. 107-116.

ten Hove, H.A. \& San Martin, G. 1995. Serpulidae (Polychaeta) from the Expedition CubanoEspanola to Isla de la Juventud and Archipelago de los Canarreos (Cuba). Stud. Nat. Hist. Carribean Reg., 72: 13-24.

ten Hove, H.A. \& Wolf, P.A. 1984. Serpulidae (Chapter 55). In: J.M. Uebelacker (ed.), Polychaete Taxonomic Standarization Project, $34 \mathrm{pp}$.

Hunte, W., Conlin, B.E. \& Marsden, J.R. 1990. Habitat selection in the tropical polychaete Spirobranchus giganteus. I. Distribution on corals. Mar. Biol., 104: 87-92.

Imajima, M. 1976a. Serpulid polychaetes from Tanega-shima, Southwest Japan. Mem. Natn. Sci. Mus., Tokyo, 9: 123-143.

Imajima, M. 1976b. Serpulinae (Annelida, Polychaeta) from Japan. I. The genus Hydroides. Bull. Natn. Sci. Mus., ser. A (Zool.), 2: 229-248.

Imajima, M. 1977. Serpulidae (Annelida, Polychaeta) collected around Chichi-jima (Ogasawara Islands). Mem. Natn. Sci. Mus., Tokyo, 10: 89-111.

Imajima, M. 1978. Serpulidae (Annelida, Polychaeta) collected around Nii-jima and O-shima, Izu Islands. Mem. Natn. Sci. Mus., Tokyo, 11: 49-72.

Imajima, M. 1979. Serpulidae (Annelida, Polychaeta) collected around Cape Shionomisaki, Kii Peninsula. Mem. Natn. Sci. Mus., Tokyo, 12: 159-183.

Imajima, M. 1987. Serpulidae (Annelida, Polychaeta) collected around Sesoko Island and Bise, Okinawa. Galaxea, 6: 75-82.

Imajima, M. \& Hartman, O. 1964. The polychaetous annelids of Japan. Pt. 2. Allan Hancock Fdn., Publ. Occ. Paper, 26: 239-452.

Marsden. J.R., Conlin, B.E. \& Hunte, W. 1990. Habitat selection in the tropical polychaete Spirobranchus giganteus II. Larval preference for corals. Mar. Biol., 104: 93-99.

Nishi, E. 1992a. Occurrence of coral boring serpulid Floriprotis 'sabiuraensis and the brooding serpulid Paraprotis dendrova. Galaxea, 11: 15-20.

Nishi, E. 1992b. Occurrence of the serpulid polychaete Serpula watsoni Willey on the living coal at Okinawa. Nanki-seibutsu, 34: 79-80. [In Japanese with English abstract]

Nishi, E. 1992c. Asexual reproduction in the serpulid tube worm, Josephella marenzelleri Caullery et Mesnil (Polychaeta, Sedentaria). Nanki-seibutsu, 34: 109-111. [In Japanese with English abstract]

Nishi, E. 1993a. On the origin of brooding characteristics in spirorbids with the phylogeny of sabellids and serpulids (Annelida, Polychaeta, Sedentaria). Proc. Jap. Soc. Syst. Zool., 49: 6-12.

Nishi, E. 1993b. Notes on reproductive biology of some serpulid polychaetes at Sesoko Island, 
Okinawa, with a brief accounts of setal morphology of three species of Salmacina and Filograna implexa. Mar. Foul., 10: 11-16.

Nishi, E. 1993c. Ecological study of a sessile polychaete Pomatoleios kraussii (Baird) (Serpulidae, Sedentaria) at Haneji Inlet, Okinawa, with fouling species composition there. Biol. Mag., Okinawa, 31: 29-40. [In Japanese with English abstract].

Nishi, E. 1995a. Occurrence of Vermiliopsis infundiburum and Pomatostegus stellatus (Polychaeta, Serpulidae) on living coral in Okinawa, Southwest Japan. Proc. Jap. Soc. Syst. Zool., 54: 28-32.

Nishi, E. \& Asakura, A. 1996. Serpulid polychaetes from Northern Mariana Islands, Micronesia. Nat. Hist. Res., 4: 19-25.

Nishi, E. \& Nishihira, M. 1993. Hermaphroditism, brooding and gamete production of Salmacina dysteri (Huxley) (Polychaeta, Annelida). Pub. Amakusa Mar. Biol. Lab., Kyushu Univ., 11: 1-11.

Nishi, E. \& Nishihira, M. 1994. Colony formation via sexual and asexual reproduction in serpulid Salmacina dysteri (Annelida, Serpulidae). Zool. Sci., 11: 589-595.

Nishi, E. \& Kikuchi, T. 1996. Preliminary observation of the tropical serpulid Spirobranchus giganteus corniculatus at Okinawa. Pub. Amakusa Mar. Biol. Lab. (in press)

Nishi, E. \& Yamasu, T. 1992a. Brooding and development of a serpulid tube worm Salmacina dysteri (Huxley) (Sedentaria, Polychaeta). Bull. Coll. Sci., Univ. Ryukyus, 54: 111-126.

Nishi, E. \& Yamasu, T. 1992b. The brooding habit and development of the serpulid Paraprotis dendrova Uchida (Annelida, Polychaeta). Bull. Coll. Sci., Univ. Ryukyus, 54: 83-93.

Nishi, E. \& Yamasu, T. 1992c. Brooding and development of the serpulid tube worm Rhodopsis pusilla Bush (Annelida, Polychaeta). Bull. Coll. Sci., Univ. Ryukyus, 54: 95-103.

Okuda, S. 1937. Polychaetous annelids from the Palau Islands and adjacent waters, the South Sea Islands. Bull. Biogeog. Soc. Japan, 7: 257-316.

Pillai, T.G. 1960. Some marine and brackish-water serpulid polychaete from Ceylon, including new genera and species. Ceylon J. Mar. Sci. (Biol. Sci.), 3: 1-40.

Pillai, T.G. 1961. Annelida Polychaeta of Tambalagan Lake, Ceylon. Ceylon J. Sci. (Biol. Sci.), 4: $1-40$.

Pillai, T.G. 1971. Studies on a collection of marine and brackish water polychaete annelids of the family Serpulidae from Ceylon. Ceylon J. Mar. Sci. (Biol. Sci.), 9: 88-130.

Pixell, H.L.M. 1913. Polychaeta of the Indian Ocean, together with some species from the Cape Verde Islands. The Serpulidae, with a classification of the genera Hydroides and Eupomatus. Trans. Linn. Soc., London (Zool.), 16: 69-92.

Scott, P.J.B. 1987. Association between corals and macro-infaunal invertebrates in Jamaica, with a list of Carribean and Atlantic coral associates. Bull. Mar. Sci., 40: 271-286.

Straughan, D. 1967. Marine Serpulidae (Annelida: Polychaeta) of Eastern Queensland and New South Wales. Aust. J. Zool., 15: 201-261.

Uchida, H. 1978. Serpulid tube worms (Polychaeta, Sedentaria) from Japan with the systematic review of the group. Bull. Mar. Park Res. St., 2: 1-98.

Uchida, H. (ed.). 1992. Lesser animals. Encyclopedia of Okinawan Marine Organisms, vol. 11, 272pp., Southern-Press Co., Okinawa. [In Japanese]

Willey, A. 1905. Report on the polychaeta collected by Professor Herdman, at Ceylon, in 1902. Rep. Pearl Oyster Fish. Mannaar, Suppl., 30, 243-324. 